\title{
Resilience of metropolitan, urban and rural regions: a Central European perspective
}

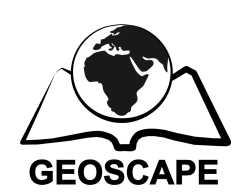

\author{
Jan Ženka ${ }^{1 *}$ - Adam Pavlík ${ }^{1}$ - Ondřej Slach ${ }^{1}$ \\ ${ }^{1}$ Department of Social Geography and Regional Development, Faculty of Science, \\ University of Ostrava, Ostrava, Czech Republic \\ *jan.zenka@osu.cz
}

\begin{abstract}
In this article, we examine a relationship between population/economic size and resilience of Czech regions. More specifically, we ask if there are any significant differences among metropolitan cores and hinterlands, urban regions and rural regions in (post)crisis economic development in the period 2009-2013. Three aspects of resilience were considered: volatility of unemployment, renewal (increase in economic performance compared to other regions) and reorientation (measured by the intensity of structural changes in total employment). We found relatively small differences among particular types of regions and high intra-group heterogeneity. Specialized industrial urban regions exhibited the fastest economic growth in the (post)crisis period. Metropolitan cores lagged slightly behind, but experienced relatively stable economic development. Although rural regions exhibited the highest unemployment volatility, they did not lag behind in terms of value added growth. Regional resilience in a small open economy like Czechia seems to be predominantly driven by extraregional factors such as the position in global production networks and economic performance in particular industries or large transnational corporations.
\end{abstract}

Key words: resilience, reorientation, metropolitan regions, urban regions, rural regions, Czechia

Highlights for public administration, management and planning:

- Post-crisis regional economic growth was driven primarily by extra-regional factors economic performance of foreign-based large transnational corporations that operate production plants in Czechia.

- Specialized industrial urban regions and rural regions performed economically better than expected, specifically those specialized in automotive and supplying industries.

- It is necessary to study regional resilience at microregional level. Analyses at NUTS3 level or comparisons of metropolitan, urban and rural regions hide significant intra-group heterogeneity.

Received: 1 May 2017 - Received in revised form 10 Jun 2017 - Accepted: 13 Jun 2017

\section{Introduction}

There have been many attempts to explain regional differences in economic growth, employment volatility and structural changes of industrial base at times of rapid externally induced economic slowdowns - regional resilience. The authors link the ability of regions to cope with external economic shocks to their population and economic size (Davies 2011), specialisation/diversity of their economic base (Dissart 2003; Ezcurra 2011; Martin et al. 2016), technological relatedness (Frenken et al. 2007), 
firm size structure (Martin \& Sunley 2015; Martin et al. 2016), human capital/skills (Lee 2012) or social capital and institutional settings (Christopherson et al. 2010; Di Caro 2015). Developed conceptual framework and plenty of empirical evidence allow us to assume that larger regions should be more resilient than smaller units, regions dominated by a single large firm either highly resistant or threatened by severe economic decline and rural regions relatively resistant to external economic impulses (both positive and negative), slowly growing at times of economic conjuncture and fairly stable at times of economic crisis.

However, the majority of authors study the above mentioned factors primarily in isolation. Few is known about the question how these factors work together in particular geographical contexts. For example, the effects of industrial specialization/diversity can be heavily influenced by population size (Beaudry et al. 2009), cyclicity of local industries (Dissart 2003), positive or negative effects of industrial legacy (Martin 2010; Henning et al. 2013) and institutional contexts such as varieties of capitalism at macroregional level and milieu at local scale (Ženka et al. 2015). There is no reason to expect that similar structural characteristics would produce similar economic effects in regions that differ significantly from each other in principal factors, actors and mechanism of regional development metropolitan regions, rural regions and mediumsized urban regions (including old industrial regions) - see Ženka et al. (2015). In each type of regions we can identify factors that should foster regional economic resilience and also factors increasing economic instability. It is a question, which effects in particular types of regions prevail and under which conditions.

In this paper we aim to fill the gap, discuss and empirically document relationships between the population size/density and regional economic resilience. More specifically, our aim is to determine if there are any fundamental differences between metropolitan regions (cores and hinterlands), medium-sized urban regions (either with or without metropolitan functions) and rural regions in economic resilience. Population and economic size/density are generally assumed to be one of the key factors of regional economic performance (Fitjar \& Rodriguez-Pose 2013) and resilience (Davies 2011). Agglomeration economies induced by the size, density and structure of regional economic base should be related to resilience, because large diversified markets in metropolitan regions:

(i) reduce employment volatility through the portfolio effect, spreading the risk of a collapse of particular firms/industries and allowing for more efficient labour market matching (Dissart 2003); (ii) foster regional adaptability thanks to high firms birth rate and innovation performance. On the other hand, concentration of financial sector and rapidly growing (but volatile) knowledgeintensive industries in metropolitan regions may increase economic instability at times of economic crises (Davies 2011). The latter should also translate into more significant shifts in industrial structure.

Metropolitan hinterlands capitalize on agglomeration effects of proximate metropolitan cores - the effects of borrowed size (Phelps \& Ozawa 2003). Combination of borrowed size and diversified industrial structure may increase resilience at times of economic crisis. At the same time, metropolitan hinterlands can profit from cost-motivated relocations of economic activities from the metropolitan cores. On the other hand, hinterlands concentrate lower value-added business-to-customer services such as retail, warehousing or logistics, that are mostly procyclical. Proximity of metropolitan cores and therefore higher costs may result into the decline of manufacturing and routine services. Therefore, deconcentration of economic activities from the hinterlands towards rural regions with even lower wages is possible to occur: a scenario analogous to the core-hinterland cost-motivated shifts of economic activities.

Rural regions cannot rely on positive effects of agglomeration economies on the ability to cope with external economic shocks. There is no consensus on the question if rural regions should be more or less resilient in comparison with urban and metropolitan regions. On one hand, low population/firm density in rural regions 
lowers efficiency of labour market matching. On the other hand, rural areas could be more resistant and should exhibit lower unemployment volatility than urban/metropolitan regions because of some distinctive structural features of rural economies: (i) higher share of non-cyclical industries such as agriculture and food industry in local employment (Ezcurra 2011); (ii) combination of diversified industrial structure and fragmented firm size structure - small and medium-sized firms in various local industries should spread the risk (Dissart 2003) and avoid negative effects of regional lock-in (Martin \& Sunley 2006); (iii) lower risk from the factors increasing economic fluctuations such as financial or real estate bubbles, rapidly growing firms developing new products and technologies in new technology-intensive industries.

We also do not know much about reactions of regions that fall between these two extremes of population size/density and agglomeration economies: medium-sized urban regions. For the purpose of this study in Czech context it is possible to divide urban regions into two basic categories: (i) urban regions with some metropolitan functions that can be treated as smaller and more specialized metropolitan regions; (ii) industrial urban regions with smaller population size dominated by a single industry, domestic firm or foreign-owned manufacturing plant (Ženka et al. 2017) that may be highly vulnerable due to their dependence on a single dominant actor or industry. It is a question if economic and employment development of medium-sized urban regions in (post)crisis period will be 'somewhere between' metropolitan and rural regions, or if their reaction will be determined by particularities of their industrial specialisation and performance of the largest local firms rather than by (lacking) agglomeration economies related to their population and economic size.

In this paper we analyze (post)crisis (2009-2013) economic development of Czech metropolitan, rural, industrial urban and urban regions with metropolitan functions in order to empirically determine if there is a relationship between the type of region and its economic resilience. Three aspects of regional economic resilience will be assessed (see Martin 2012 for theoretical discussion):

(a) Stability/volatility - meaning the ability of regions to avoid significant employment fluctuations in the (post)crisis period

(b) Renewal - distinguishing between regions that have returned to the growth trajectory and improved their relative economic performance in the post-crisis period compared to the pre-crisis period and regions that have lagged behind and their ranking of economic performance fell (relatively to other regions or even absolutely).

(c) Reorientation - to what extent have industrial and firm size structures changed in order to adapt to changing external conditions or, on the contrary, have changed as a result of failed regional adaptation

Based on above mentioned discussion we aim to answer several research questions:

RQ1: Are there any fundamental differences in economic development between Czech metropolitan, urban and rural regions in the (post)crisis period (2009-2013)? If yes:

RQ2: Which regions have improved their economic performance in the (post)crisis period and which regions have lagged behind? To what extent can be these differences explained by agglomeration economies derived from their population/economic size?

RQ3: Are there any relationships between the degree of renewal and reorientation? In other words, which regions performed economically better: those that underwent significant changes in their industrial structure or rather those that showed continuity of industrial structure?

In the following sections we provide more detailed theoretical discussion of assumed relationships between the type of regions and their economic resilience. Third section relates theoretical discussion of regional resilience to specific geographical context of Central Europe. In section four we specify data sources and methods. Fifth section provides the most important empirical results, while the final section six provides answers for the research 
questions, concludes and proposes recommendations for future research.

\section{Contextualisation - Czech metropolitan, urban and rural regions}

In the first section we discussed general factors of regional resilience such as population size, specialization/diversity or firm size structure. As already mentioned, however, effects of these factors are always mediated by various geographical contexts. It is not justifiable to expect that Czech regions will react to external economic shocks in the same way as their Western/Southern European counterparts, for which extensive empirical evidence has been collected. Therefore, in this section we focus on the most important contextual features of Central European (namely Czech) metropolitan, urban and rural regions.

Czech metropolitan cores are very heterogeneous in their population/economic size. Praha representing a global gamma city has all features that are associated with economically successful metropolitan regions: large diversified market and population size allowing for urbanization economies to take significant effect, gateway function (Ženka et al. 2017), concentration of corporate headquarters and foreign-owned banks (Blažek \& Bečičová 2016) that profit from mutually beneficial face-to-face contacts with large and diverse sector of knowledge-intensive business services. Although Brno is characteristic by high concentration of universities, knowledgeintensive business services (mostly information technologies) and developed regional innovation system (Ženka et al. 2017), its relatively small size, weakly developed financial sector and limited presence of corporate headquarters limit the potential for robust renewal driven by endogenous innovations. The same holds also for Ostrava that was traditionally specialized in coal mining and metallurgy, currently showing significantly lower share of knowledge-intensive business services that are oriented rather on routine lower value-added activities (Blažek et al. 2011).

In commuting hinterlands of Czech metropolitan regions it is possible to find the majority of fast growing regions (Maier \& Franke 2015). Nevertheless, it is primarily a social dynamics expressed by the population growth and real estate development, driven by an intensive residential suburbanization (Sýkora \& Mulíček 2012). On the other hand, spatial deconcentration of jobs driven by the commercial suburbanization is rather limited. There is some evidence that manufacturing and less knowledgeintensive services move from the metropolitan cores to their hinterlands, but commercial suburbanization of knowledge-intensive business services or creative industrial is rather weak and restricted primarily to Prague metropolitan region (Slach et al. 2017).

Czech urban regions with metropolitan functions play the role of administrative centres of NUTS3 regions. These medium-sized units (from roughly 100000 to 300000 inhabitants) do not show very high population/firm densities, because their commuting hinterlands are usually relatively sparsely populated (especially around Plzeň, České Budějovice and Jihlava, Ústí nad Labem is an exception). Although all urban centres of these regions show above average economic performance in Czech context, their per capita value added varies significantly. Successfully transformed cities such as Plzeň, České Budějovice and Jihlava perform significantly better than Ústí nad Labem (urban centre of an old industrial regions) or Karlovy Vary characteristic by one-sided industrial specialization. While most of these regions lag behind metropolitan cores in terms of economic performance (Table 1), some industrial urban and even rural regions that are dominated by large manufacturing firms exhibit significantly higher value added per capita (such as Mladá Boleslav, Třinec or Kopřivnice).

Urban regions with metropolitan functions are characteristic by relatively high share of public services that reflect their administrative function. Public services are generally anti-cyclical and may thus reduce employment volatility at times of crises, stabilize regional economy (RodriguézPose \& Fratesi 2003; Ezcurra 2011). At the same time, compared to metropolitan cores these regions show more specialized industrial structure and relatively strong role of large firms. 
Therefore, it is not likely that Czech urban regions with metropolitan functions will react to economic crisis in the same way as larger and more diversified metropolitan cores, their reaction can be closer to industrial urban regions.

Compared to previous group industrial urban regions are characteristic by smaller population/economic size and significantly higher rate of industrial specialization. As such, they should be more sensitive to external economic shocks and, at the same time, their rate of recovery in the post-crisis period can be relatively fast (Hill et al. 2011). On the other hand, industrial urban regions may vary significantly in resilience. It is not that important if the region has specialized or diversified industrial structure, but which particular (cyclical or non-cyclical, growing or declining) industries are present (Kemeny \& Storper 2015). Even highly specialized regions may be thus resilient (Martin 2012).

Table 1 - Basic characteristics of metropolitan, urban and rural regions (2013)

\begin{tabular}{|c|c|c|c|c|c|c|c|c|c|}
\hline & \multicolumn{3}{|c|}{ Share in Czechia (\%) } & \multirow{2}{*}{$\begin{array}{l}\text { thous. CZK } \\
\begin{array}{l}\text { Value added } \\
\text { per capita }\end{array} \\
\end{array}$} & & \multicolumn{3}{|c|}{$\begin{array}{l}\text { Share of sectors } \\
\text { in employment (\%) }\end{array}$} & \multirow[b]{2}{*}{ SERV } \\
\hline & Population & Employment & Value added & & & AGR & MAN & CON & \\
\hline $\begin{array}{l}\text { Metropolitan cores } \\
\text { Metropolitan }\end{array}$ & 18.5 & 30.0 & 35.0 & & 298 & 0.5 & 24.9 & 11.2 & 63.4 \\
\hline $\begin{array}{l}\text { hinterlands } \\
\text { Urban regions with }\end{array}$ & 10.8 & 6.7 & 6.6 & & 96 & 4.0 & 52.6 & 11.2 & 32.1 \\
\hline metropolitan functions & 16.0 & 17.9 & 16.8 & & 165 & 2.5 & 51.4 & 12.0 & 34.2 \\
\hline Industrial urban regions & 10.4 & 10.0 & 11.1 & & 169 & 1.7 & 65.6 & 9.0 & 23.7 \\
\hline Rural regions & 44.2 & 35.4 & 30.5 & & 109 & 7.5 & 65.2 & 9.1 & 18.3 \\
\hline Czechia & 100.0 & 100.0 & 100.0 & & 158 & 3.7 & 49.8 & 10.4 & 36.1 \\
\hline
\end{tabular}

Rural regions are generally relatively highly urbanized and heavily industrialized (Ženka et al. 2015). In fact, there is no purely agricultural rural region in Czechia. In all Czech rural regions manufacturing accounts for higher share in value added than agriculture and forestry (CSO 2013) see Table 1. Dependence on manufacturing is comparable to industrial urban regions, while, not surprisingly, the importance of business services is very limited. Rural regions account for $44.2 \%$ of Czech population and roughly one third of employment and value added, figures comparable to the metropolitan cores (CSO 2013). Although their economic performance is significantly lower than national average, overall numbers obscure very high internal heterogeneity: in 2013 value added per capita in Czech rural regions ranged from 325 thous. CZK (Jičín) to 36 thous. CZK (Jablunkov) and twelve rural regions exceeded national average. Rural regions in Czechia also vary significantly in their economic structure - while most of them are characteristic by diversified industrial structure, fragmented firm size structure and higher share of agriculture and food industries, some of them are rather specialized on other low to mediumtech manufacturing industries such as glass (Železný Brod, Nový Bor) or wood products and furniture (Pacov, Bystřice pod Hostýnem).

\section{Methods}

We start this section by an introduction of the approach we used to define metropolitan, urban and rural regions in Czechia. For delimitation of metropolitan regions the OECD publication "Redefining Urban" (2012) was used. OECD defines metropolitan regions as densely populated urban cores with more than 50,000 inhabitants that are merged with surrounding municipalities, characteristic by $15 \%$ or higher share of employed residents commuting to the nearest urban core (OECD 2012). In Czechia only three metropolitan regions were delimited: the 
largest cities (Praha, Brno, Ostrava) and their metropolitan hinterlands. Because of limits in data availability we had to merge metropolitan regions from the so called municipalities with extended competences that roughly correspond to nodal microregions (based on approach of Kraft et al. 2014) - see Fig. 1. Correspondingly, definition of urban regions with metropolitan functions was also based on OECD and corresponds with administrative centres of
NUTS3 regions (Most and Chomutov were therefore excluded).Industrial urban regions cover densely inhabited small and medium-sized cities with their commuting hinterlands, characteristic by a strong manufacturing base and dominance of large manufacturing firms: therefore all remaining units that cannot be considered rural.

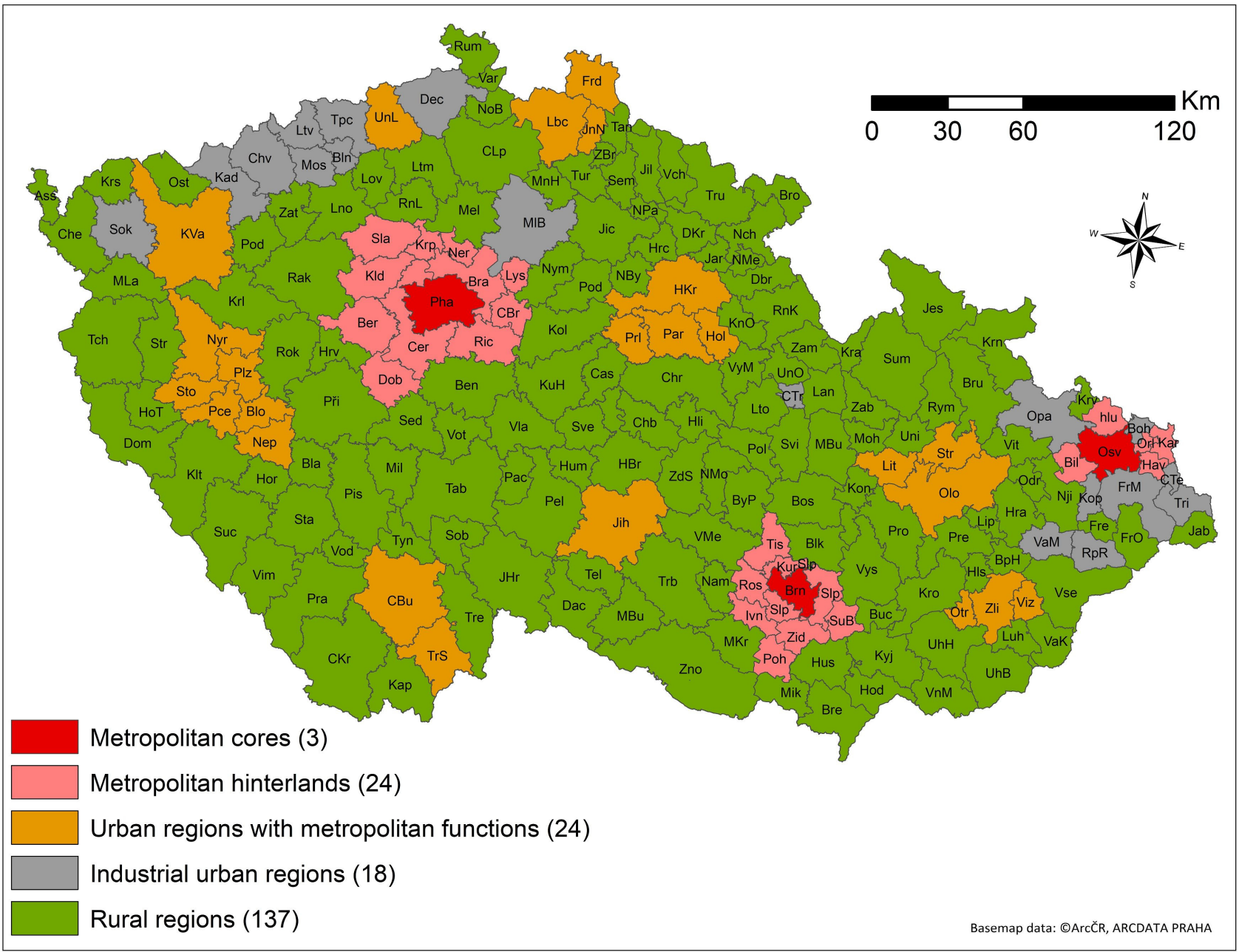

Fig. 1 - Delimitation of metropolitan, urban and rural regions in Czechia (source: the authors departing from OECD (2012); Kraft et al. (2014); Hampl (2005))

Identification of rural regions was based on three criteria: dispersion of the settlement structure, low population density and low spatial productivity, suggesting higher share of agriculture and limited presence of high value- added knowledge-intensive economic activities. Dispersion of the settlement structure was measured by the share of municipalities with less than 3000 inhabitants (CSO 2016). Because some municipalities with extended competences are 
small in terms of area and population, share of urban cores in total population may be higher than the share of rural hinterlands. Density was calculated by population per one hectare of built- up area (CSO 2016) and spatial productivity as value-added per one hectare of built-up area (CSO 2013) - see Table 2. We calculated an index of rurality:

Index of rurality $=\frac{\text { settlement dispersion }+2 * \text { population density }+2 * \text { spatial productivity }}{5}$

Regional economic data (employment, valueadded, industrial structure) for the period 2009-2013 were obtained from the unique database of the Czech Statistical Office (CSO 2013), aggregated for the municipalities with extended competences and 2-digital NACE rev. 2.0 sectoral aggregation. The database does not cover all industries of the Czech economy. Statistical data are available for the agriculture and forestry, manufacturing, construction and most of business services (NACE 49-56; 58-64; 66;
68 ; 69-75; 77-82), while data for the mining, energy, public services and some consumer and commercial services (such as wholesale, retail and the repair of motor vehicles) are missing. Total employment and value added of municipalities with extended powers were thus calculated only for industries for which there were data available on a micro-regional level; they do not represent the entire spectrum of local economic activities.

Table 2 - Indicators employed in regional analysis

\begin{tabular}{llll} 
Variable & Indicator & Period & Data source \\
\hline $\begin{array}{l}\text { Settlement } \\
\text { dispersion }\end{array}$ & $\begin{array}{l}\text { Share of municipalities with less than 3,000 } \\
\text { inhabitants in population (\%) }\end{array}$ & 2016 & CSO 2016 \\
$\begin{array}{l}\text { Spatial productivity } \\
\text { Rurality }\end{array}$ & $\begin{array}{l}\text { Population per one ha of the bulit-up area } \\
\text { Value-added per one ha of the built-up area }\end{array}$ & 2013 & CSO 2016 \\
Index of rurality & 2013 & $\begin{array}{l}\text { CSO 2013; CSO 2017; } \\
\text { Ženka et al. 2015 }\end{array}$ \\
Volatility & $\begin{array}{l}\text { Variation coefficient of monthly } \\
\text { unemployment rates } \\
\text { Change in the ranking of regions according } \\
\text { Renewal }\end{array}$ & 2009-2013 & MLSA 2014 \\
to their relative economic performance & & CSO 2009; CSO 2013 \\
Reorientation & $\begin{array}{l}\text { Finger-Kreinin index of structural shifts } \\
\text { in employment }\end{array}$ & $2009-2013$ & CSO 2009; CSO 2013
\end{tabular}

Note: The first four indicators were used for delimitation of rural regions. The last three indicators measure basic dimensions of regional resilience - unemployment volatility, degree of renewal and reorientation of the regional economy.

Degree of renewal was measured by changes in relative economic performance of regions in the period 2009-2013. For the year 2009 all regions were ranked according to their value-added per capita, the same was done for the year 2013. Next, we subtracted regional rankings in 2009 from 2013 rankings and identified regions that improved their relative economic performance compared to other regions that lost ground in the (post)crisis period 2009-2013. Unemployment volatility was measured by the variation coefficient of monthly employment levels in the 
period 06/2005-12/2011. Finally, degree of reorientation was captured by the Finger-Kreinin index, formally denoted as:

$$
F K I_{t 1, t 2}=0.5 \sum_{k}\left|e_{k t 1}-e_{k t 2}\right|
$$

where $e_{k}$ represents the share of employment in industry $k$ in total employment of the region (groups of regions), $t_{1}$ and $t_{2}$ index two points in time. High values of the index signify intensive changes of employment structure, low values point to regions that have maintained their original specialization without any significant changes.

\section{Results}

Let us start with a basic description of changes in spatial distribution of economic activities. Table 3 shows that in the period 2009-2013 no significant spatial reallocation of employment occurred. Metropolitan cores slightly increased their share in overall employment, but there were only minor differences among other groups of regions. Changes are more apparent when measured by value added. Surprisingly, nonmetropolitan regions performed better than metropolitan cores/hinterlands that registered slight decreases both in absolute and relative figures. Industrial urban regions showed the highest increase in value added and even rural regions outperformed their metropolitan counterparts.

The same holds also for the changes in economic performance that were driven by the development of value added rather than employment that remained relatively constant. Out of all 206 regions almost one half (92) exhibited decreases in employment and value added - all three metropolitan cores, more than half metropolitan hinterlands and 55 of them were rural regions. Correspondingly, out of 114 economically growing regions 82 were rural and 14 urban with metropolitan functions. Apart from the metropolitan cores all groups of regions included both economically growing and falling units.

Table 3 - 2009-2013 employment and value-added growth; structural changes and volatility (source: CSO 2009; CSO 2013; MLSA 2014)

\begin{tabular}{|c|c|c|c|c|c|c|c|c|}
\hline \multirow[b]{3}{*}{ Metropolitan cores } & \multicolumn{3}{|l|}{ Employment } & \multicolumn{2}{|c|}{$\begin{array}{l}\text { Value added } \\
\text { (mil. CZK) }\end{array}$} & \multicolumn{2}{|r|}{ Reorientation } & \multirow{2}{*}{$\begin{array}{l}\text { Unemployment } \\
\text { volatility } \\
\text { Variation } \\
\text { coefficient }\end{array}$} \\
\hline & 2009 & 2013 & Index & 2009 & 2013 & Index & FKI & \\
\hline & 620642 & 632966 & 102 & 589 & 580 & 98 & 10.1 & 0.455 \\
\hline $\begin{array}{l}\text { Metropolitan hinterlands } \\
\text { Urban regions with }\end{array}$ & 150033 & 141769 & 94 & 112 & 109 & 98 & 15.7 & 1.985 \\
\hline metropolitan functions & 392267 & 376493 & 96 & 274 & 278 & 102 & 14.0 & 1.951 \\
\hline Industrial urban regions & 225062 & 210238 & 93 & 155 & 185 & 120 & 16.0 & 1.583 \\
\hline Rural regions & 791120 & 747324 & 94 & 486 & 506 & 104 & 14.9 & 4.528 \\
\hline Czechia & 2179124 & 2108790 & 97 & 1616 & 1659 & 103 & & 5.087 \\
\hline
\end{tabular}

At microregional level there was no clear spatial pattern of economic growth or decline (see Fig. 2). Apart from the fact that all metropolitan cores and most regions in their hinterlands exhibited decreasing economic performance, it is difficult to find regularities in economic performance of urban regions with metropolitan functions, industrial urban regions and rural regions. The best performers (Vodňany, Stod, Nový Jičín, Železný Brod, Odry, Světlá nad Sázavou, Kadaň) 
have few common features, small population and economic size is one of them. On the other hand, among the worst performers we can find such diverse regions as sparsely populated peripheries (Votice, Havlíčkův Brod, Krnov), old industrial regions (Most), regions with significant role of intensive agricultural production (Holešov, Nymburk) or some industrialized metropolitan hinterlands (Brandýs nad Labem).

It would be tempting to explain regional differences in economic growth by structural changes: regions that underwent significant shifts in industrial structure can be intuitively viewed as dynamic adaptable units that should grow faster than regions with persistent industrial structure. Nevertheless, Fig. 3 clearly shows that there is no statistical relationship between 2009-2013 changes in relative economic performance of regions (ranking) and intensity of structural changes in employment $(\mathrm{R}=0.048)$. Some regions that underwent significant changes in their industrial structures exhibited decreasing economic performance (e.g. Frenštát pod Radhoštěm, Slavkov u Brna, Roudnice nad Labem, Bohumín), while other regions improved significantly their ranking in economic performance (e.g. Votice, Jičín, Nový Jičín, Přeštice).

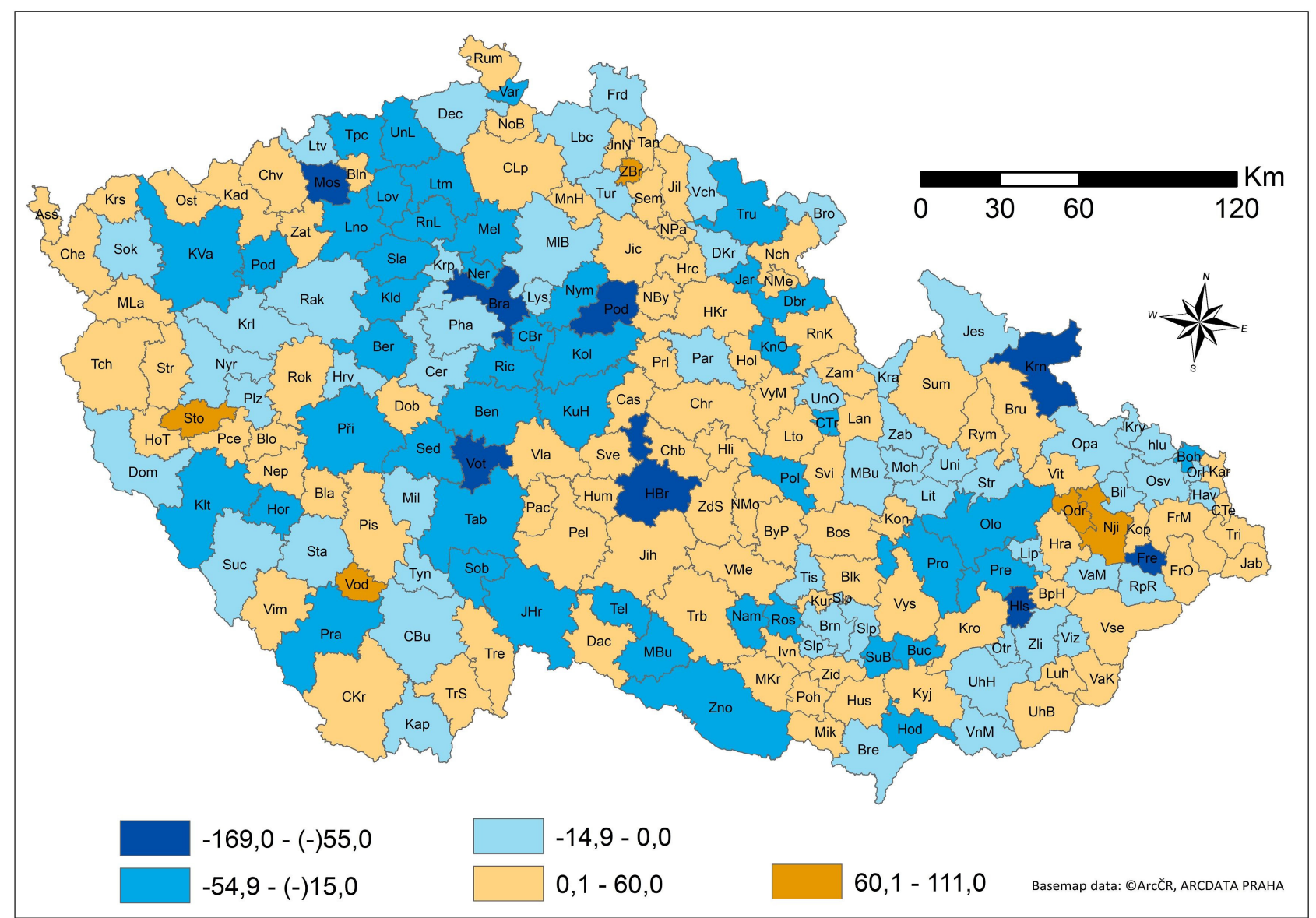

Fig. 2 - Renewal: 2009-2013 changes in the ranking of regions according to their economic performance (source: the authors based on CSO 2009; CSO 2013) 


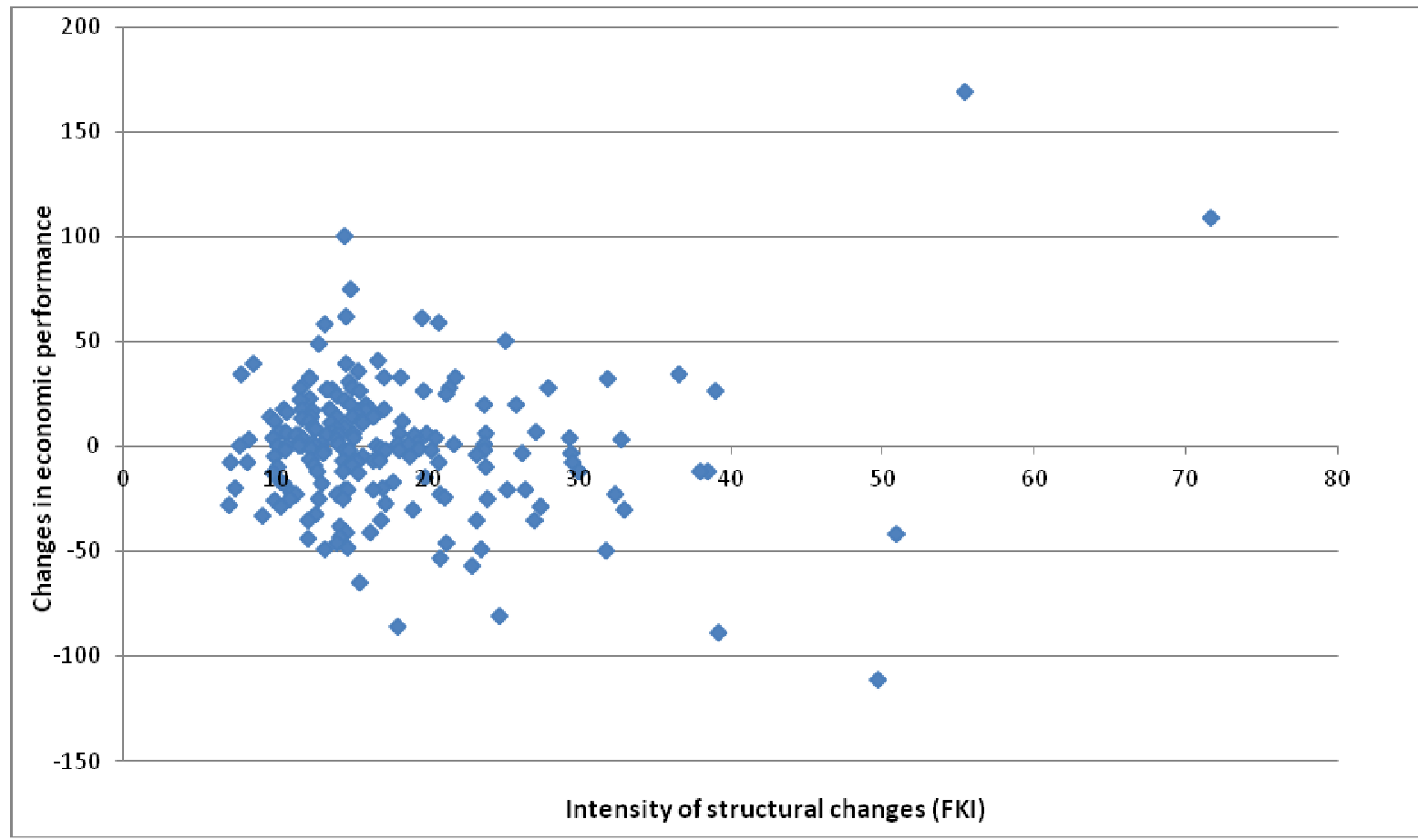

Fig. 3 - Relationship between the intensity of structural changes and changes in economic performance of regions in the period 2009-2013 (source: the authors based on CSO 2009; CSO 2013; MLSA 2014)

We did not find any major differences in the degree of reorientation among metropolitan, urban and rural regions (Table 3,4). The only (and surprising) exception is lower intensity of structural changes in the group of metropolitan cores. After exclusion of the three largest Czech cities there remain only minor differences in the degree of reorientation. On the other hand, the largest differences between particular types of regions were recorded in the analysis of regional resistance - monthly unemployment volatility in the period 6/2008-12/2011. Rural regions showed the highest unemployment volatility of all groups, while metropolitan cores the lowest.

Table 4 - Regional resilience in the period 2009-2013: descriptive statistics (source: CSO 2009; CSO 2013;MLSA 2014)

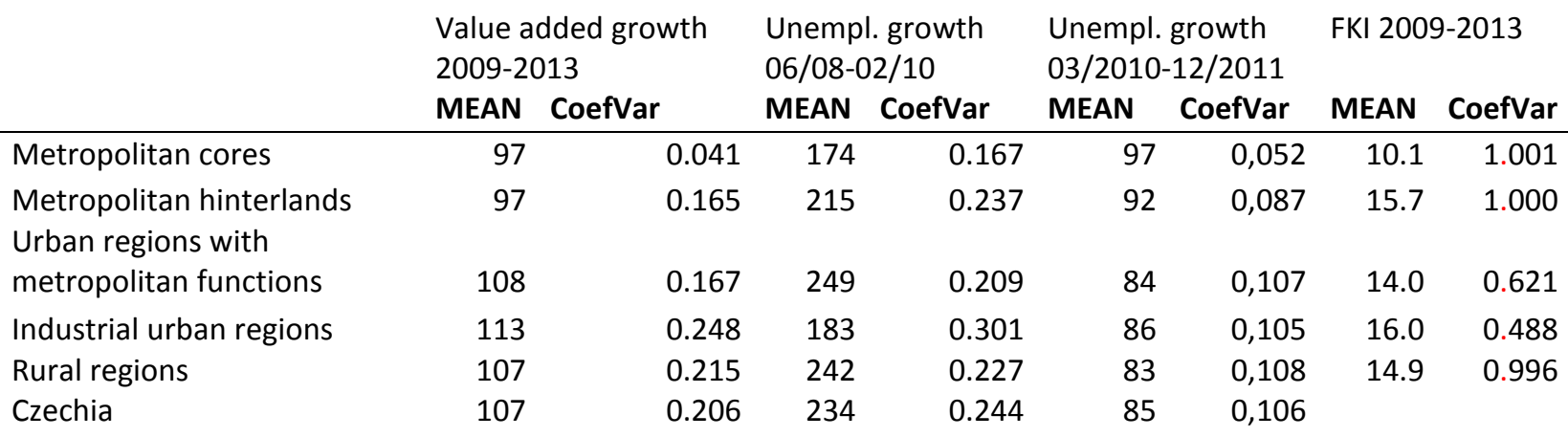

Note: CoefVar - coefficient of variation (standard deviation divided by the mean) 


\section{Discussion}

Empirical results show that (post)crisis economic development of particular types of regions (metropolitan cores and hinterlands, urban regions with metropolitan functions, industrial urban and rural regions) corresponds only partially with theoretically expected scenarios. Metropolitan cores exhibited relatively high stability of their economic development, low unemployment rates and low unemployment fluctuations, which confirms the predictions that regions with large, diversified and flexible markets will profit the most from the portfolio effect stabilizing local economy (Malizia \& Ke 1993; Frenken et al. 2007). Martin and Sunley (2006, p. 421) argue that "there is a trade-off between specialization and a short-lived burst of fast regional growth on the one hand, and diversity and continual regional adaptability on the other." This theoretical statement was also to certain degree empirically confirmed. Diversified metropolitan cores in the post-crisis period lagged behind specialized industrial urban regions that grew faster. On the other hand, metropolitan cores showed the lowest intensity of changes in industrial structure. The opposite could be expected from the theoretical discussion of large cities nursing innovations and growth of new industries (Duranton \& Puga 2001). We also did not observe unemployment fluctuations resulting from the concentration of highly cyclical industries such as finances and burst of real estate bubbles (Davies 2011).

Metropolitan hinterlands performed worse than could be expected from favourable combination of urbanization economies available in proximate metropolitan cores and lower prices. We did not identify large scale commercial suburbanization from the cores to their hinterland at times of economic crisis. Deconcentration was relatively weak especially for higher value-added services (see also Slach et al. 2017) - with certain exception of the metropolitan region of Prague. Results were closer to the findings of Monsson (2015) that metropolitan cores may "push" the recessionary shocks to their hinterlands in which unemployment grows faster.
Industrial urban and rural regions on average improved their economic performance in the (post)crisis period in comparison with other types of regions. We did not confirm a hypothesized causal effect of specialization in agriculture on reduction of unemployment volatility, as suggested by Ezcurra (2011). On the contrary, rural and also industrial urban regions exhibited the highest rates of unemployment volatility, which should be related to the combination of small size, specialization and high export orientation. Rodríguez-Pose and Fratesi (2003) argue that regions with a significant share of public services, characteristic by the "sheltered economy", should be more stable than exportoriented areas. We did not confirm validity of this expectation for Czech rural/peripheral regions, which are highly industrialized and exportoriented, therefore more susceptible to economic unstability (in line with argumentation of Hill et al. 2011). Nevertheless, this finding is also valid for rural peripheries in Eastern Poland (Masik \& Rzyski 2014) and Slovakia (Pauhofová \& Želinský 2015; Korec et al. 2016). At NUTS2 level, on the other hand, agricultural peripheries in Poland and Romania experienced smaller unemployment increases (Blažek \& Netrdová 2012a). Higher share of public services and lower export orientation may generally lower unemployment volatility rather in the group of urban regions with metropolitan functions and also metropolitan cores.

Other authors who focus on regional resilience and unemployment in Central Europe in the (post)crisis period (since 2008) generally agree that rural regions were not only more volatile, but also their economic performance (measured mostly by unemployment rates) deteriorated in comparison with other regions - see table 5 . On the other hand, Pileček et al. (2010) or Toušek and Novák (2012) argued that Czech rural regions specialized in traditional manufacturing industries recorded the highest unemployment growths in the crisis period. We did not deny this tendency. If we look also at the post-crisis economic development, however, we argue that Czech rural regions in general grew faster than other types of regions due to rapid renewal of several rural manufacturing centres (mostly those 
specialized in automotive industry) that compensated falls of the above mentioned rural regions specialized in traditional (mostly labourintensive) industries.

Table 5 - Selected literature on the (post)crisis spatial development, regional resilience and unemployment in Central Europe

\begin{tabular}{|c|c|c|c|c|}
\hline Title & Country/Area & Spatial unit & Period & Findings \\
\hline $\begin{array}{l}\text { Blažek \& } \\
\text { Netrdová } \\
\text { (2012a) }\end{array}$ & $\begin{array}{l}\text { East-Central } \\
\text { Europe }\end{array}$ & NUTS3, LAU1 & $\begin{array}{l}06 / 2008- \\
07 / 2010\end{array}$ & $\begin{array}{l}\text { Decline in inter-regional variability in unemployment rate - } \\
\text { "convergence in misery". In Czechia and Slovakia capital cities } \\
\text { and urban regions with metropolitan functions experienced } \\
\text { smaller increase in unemployment than rural regions; west- } \\
\text { east gradient of resilience (especially in Hungary); low } \\
\text { unemployment growth in rural peripheries oriented on } \\
\text { agriculture in Poland and Romania. }\end{array}$ \\
\hline
\end{tabular}

Hruška (2014) Czechia Municipalities 1991-

2011

Toušek \& Novák Czechia

(2012)

\begin{tabular}{|c|c|c|c|}
\hline $\begin{array}{l}\text { Ženka et al. } \\
\text { (2015) }\end{array}$ & Czechia & Microregions & $\begin{array}{l}2008- \\
2009\end{array}$ \\
\hline $\begin{array}{l}\text { Blažek \& } \\
\text { Netrdová } \\
\text { (2012b) }\end{array}$ & Czechia & Municipalities & $\begin{array}{l}2002- \\
2011\end{array}$ \\
\hline $\begin{array}{l}\text { Pavlínek \& } \\
\text { Ženka (2010) }\end{array}$ & Czechia & $\begin{array}{l}\text { Microregions, } \\
\text { firms }\end{array}$ & $\begin{array}{l}06 / 2008 \\
06 / 2009\end{array}$ \\
\hline $\begin{array}{l}\text { Pileček et al. } \\
(2010)\end{array}$ & Czechia & LAU2, LAU1 & $\begin{array}{l}03 / 2008 \\
03 / 2009\end{array}$ \\
\hline
\end{tabular}

Pavlík (2016) Czechia

Microregions

2008-

2011

Pauhofová \&

Slovakia

NUTS3, LAU1

2006-

2013
Larger rural municipalities in Moravskoslezský regions close to the cities and transport corridors were the most resilient due to their entrepreneurial base and diversified economy (with certain exception of municipalities dependent on foreignowned manufacturing branch plants). Peripheral rural municapilities showed the lowest resilience.

06/2008- The authors identified convergence in relative regional $03 / 2010$ variability in the unemployment rate during the crisis period. Unemployment in old industrial regions grew less than in (mostly) rural regions specialized in lower-tech manufacturing (glass, porcelain and ceramic products, textiles, apparel, leather products). Urban (and metropolitan) regions experienced slower unemployment increases than rural regions.

Rural and industrial urban regions dependent on manufacturing reported highest unemployment increases, no matter if their industrial base was specialized or diversified.

Spatial pattern of unemployment has become more fragmented. The authors identified decreasing tendency of municipalicities with high unemployment rates to cluster spatially.

Crisis in the automotive industry did not alter significantly regional unemployment patterns. Position of regions in global production networks was not associated with unemployment growth.

Two types of rural regions exhibited rapid unemployment growth: (a) regions close to Czech-Polish border and (b) internal peripheries on the borders between Czech NUTS3 regions. Fast unemployment growth was associated mostly with regional specialization on machinery/automotive or textile industries and dominant position of a single large firm or manufacturing plant.

Czech non-metropolitan regions were very heterogeneous in their reactions to the economic crisis. Specialized nonmetropolitan regions that performed economically well before the pre-crisis showed the fastest unemployment growth in the crisis period, while diverse regions with fragmented firm size structure exhibited the most successful recovery.

Increasing regional polarization of wages (measured by Moran I); rural districts in Košický, Prešovský and Bánskobystrický region were hit most by decreasing wages. 
Table 5 (continued) - Selected literature on the (post)crisis spatial development, regional resilience and unemployment in Central Europe

\begin{tabular}{|c|c|c|c|c|}
\hline Title & Country/Area & Spatial unit & Period & Findings \\
\hline $\begin{array}{l}\text { Korec et al. } \\
(2016)\end{array}$ & Slovakia & LAU1 & $\begin{array}{l}2001- \\
2015\end{array}$ & $\begin{array}{l}\text { "Convergence in misery" was reported in the crisis period. } \\
\text { Some peripheral rural regions showed unemployment } \\
\text { increases in the post-crisis period. }\end{array}$ \\
\hline Kiss (2012) & Hungary & NUTS3 & $\begin{array}{l}2007- \\
2009\end{array}$ & $\begin{array}{l}\text { Highly industrialized north-western regions that experienced a } \\
\text { rapid FDI-driven pre-crisis economic growth reported the } \\
\text { fastest unemployment increases in the period of crisis. }\end{array}$ \\
\hline $\begin{array}{l}\text { Masik \& Rzyski } \\
\text { (2014) }\end{array}$ & Poland & NUTS2 & $\begin{array}{l}2007- \\
2012\end{array}$ & $\begin{array}{l}\text { Peripheral rural regions showed the lowest resilience in the } \\
\text { (post)crisis period, regions with metropolitan cores the } \\
\text { highest. }\end{array}$ \\
\hline
\end{tabular}

\section{Conclusions}

In this paper we examined the relationship between agglomeration economies and regional resilience. More specifically, we asked if there are any significant differences between metropolitan, urban and rural regions in their ability to resist to external economic shocks. In addition, we also tested possible relationships between the intensity of structural changes in the post-crisis period (2009-2013) and the degree of renewal measured by the growth of per capita value added. Our aim was to move beyond prevailing studies that analyze particular factors of regional resilience (such as population size, specialization/diversity of the economic base) in isolation. Effects of population/economic size, industrial or firm size structure on regional resilience are not necessarily the same in regions that differ significantly in their principal factors, actors and mechanisms of regional development - such as metropolitan cores, metropolitan hinterlands, urban regions with/without metropolitan functions and rural regions differ from each other. Drawing on the case study of (post)crisis economic and employment growth of Czech regions we tried to determine how these factors operate in various geographical contexts.

The first research question was if and to what extent do particular types of Czech regions (metropolitan cores and hinterlands, urban regions with metropolitan functions, industrial urban regions and rural regions) vary in their reactions to 2008-2009 economic crisis. When measured by employment growth we found only

minor differences among the analysed groups of regions. Value added growth varied more, but differences between groups of regions were relatively insignificant (with certain exception of industrial urban regions) compared to high intragroup heterogeneity. Therefore, regional typology based on the potential for agglomeration economies was not sufficient to explain differences in regional economic and employment growth in the (post)crisis period. With decreasing population/economic size of regions the heterogeneity of regional reactions to economic crisis is rising - rural regions were the most diverse in their (post)crisis dynamics of employment and value added growth.

In the second research question we asked which regions improved their relative economic performance in the (post)crisis period and which lagged behind. While inter-group differences are not too high, maybe the most surprising empirical result is that the position of metropolitan cores and their hinterlands slightly deteriorated, while industrial urban regions exhibited the fastest increase in value added. It seems that innovationdriven renewal in diversified metropolitan regions affected the overall results significantly less than renewal in some industrial urban regions. At the level of municipalities with extended competences we argue that resistance and renewal are primarily driven by economic performance of individual large firms (mostly foreign-owned) and their extra-regional linkages. Therefore, small economic size, highly specialized industrial structure and concentrated firm size 
structure - combination that was expected to cause economic decline or at least instability lead in several industrial urban and rural regions to significantly improved relative economic performance.

Third and last research question was focused on the relationship between the intensity of structural changes and regional renewal. We asked which regions performed economically better in the (post)crisis period - those that underwent deep changes in industrial structure or those characteristic by persistent industrial mix. No effect of the intensity of structural changes on regional economic performance in the (post)crisis period was detected. Therefore, various ways of renewal were identified, some were based on upgrading of local industries and large firms (mostly in the automotive industry and supplier industries) without significant changes in industrial structure, the others underwent significant shifts towards new industries and there were also cases of regions that experienced decreasing economic performance due to the collapse of the local dominant firms or industry. We find no evidence that shifts to new higher value-added industries were necessary for successful post-crisis economic development.

Our study clearly demonstrated high differences in trajectories of renewal at microregional level. Therefore, neither analyses at NUTS2/NUTS3 level nor comparisons of various types of regions (metropolitan, urban, rural) are sufficient for explanation of regional differences in resilience. Nevertheless, no clear regional patterns of volatility and renewal were identified. At microregional level the reactions to external economic shocks are driven primarily by economic performance of individual large firms. Perhaps most importantly, regional resilience in a small open economy like Czechia seems to be predominantly driven by extra-regional factors.

\section{Acknowledgements}

This research was supported by the research project SGS12/PřF/2017 "The role of service in development of industrial cities and regions."

\section{References}

Beaudry C, Schiffauerova A (2009) Who's right, Marshall or Jacobs? The localization versus urbanization debate. Research Policy 38(2): 318-337.

Blažek, J., Žížalová, P., Rumpel, P., Skokan, K. (2011) Where does the knowledge for knowledgeintensiveindustries come from? The case of biotech in Prague and ICT in Ostrava, European Planning Studies 19(7): 1277-1303.

Blažek, J., Netrdová, P. (2012a) Aktuální tendence lokální diferenciacevybraných socioekonomických jevů v Česku: směřuje vývoj $k$ větší mozaikovitosti. Geografie 117(3): 266-288.

Blažek, J., Netrdová, P. (2012b) Regional unemployment impacts of the global financial crisis in the new member states of the EU in Central and Eastern Europe. European Urban and Regional Studies 19(1): 42-61.

Blažek J, Bečicová I (2016) The takover of Pragues's banking cluster by multinational groups from an evolutionary perspectie. Geografie 121(2): 254-278.

Čsú (2009) Roční výkaz ekonomických subjektů vybraných produkčních odvětví za rok 2009. Český statistický úřad, Praha.

ČSú (2013) Roční výkaz ekonomických subjektů vybraných produkčních odvětví za rok 2013. Český statistický úřad, Praha.

Čsú (2016) Počet obyvatel v obcích k 1. 1. 2016. Český statistický úřad, Praha.

Davies S (2011) Regional resilience in the 2008-2010 downturn: comparative evidence from European countries. Cambridge Journal of Regions, Economy and Socienty 4: 369-382.

Di Caro P (2015) Testing and eplaining economic resilience with an application to Italian regions. Papers in Regional Science 1-21.

Dissart C J (2003) Regional Economic Diversity and Regional Economic Stability: Research Results and Agenda. International Regional Science Review 26(4): 423-446.

Duranton G, Puga D (2001) Nursery cities. American Economic Review 91: 1454-1475.

Ezcurra R (2011) Unemployment Volatility and Regional Specialization in the European Union. Regional Studies 45(8): 1121-1137.

Fitjar R D, Rodríguez-Pose A (2013) Buzz, archipelago economies and the future of intermediate and peripheral areas in a spiky world. European Planning Studies 21: 355-372. 
Frenken K, Oort Van F, Verburg T (2007) Related Variety, Unrelated Variety and Regional Economic Growth. Regional Studies 41(5): 685-697.

Hampl M. (2005) Geografická organizace společnosti v České Republice: transformační procesy a jejich obecný kontext. Univerzita Karlova, Praha.

Henning, M., Stam, E., Wenting, R. (2013) Path dependence research in regional economic development: Cacophony or knowledge accumulation? Regional Studies 47: 1348-1362.

Hill E, St. Clair T, et al (2011) Economic shocks and regional economic resilience - working paper. Building Resilient Regions, UC Berkeley Institute of Governmental Studies, California.

Hruška V (2014) Ekonomická resilience venkovských lokalit Moravskoslezského kraje $v$ transformačním období. In: Raška P, Hruška V (eds.) Adaptabilita a resilience. Univerzita J.E. Purkyně, Ústí nad Labem, pp. 79-102.

Christopherson S, Michie J, Tyler P (2010) Regional resilience: theoretical and empirical perspective. Cambridge Journal of Regions, Economy and Socienty 3(1): 3-10.

Kemeny T, Storper M (2015) Is Specialisation Good for Regional Economic Development? Regional Studies 49(6): 1003-1018.

Kiss, E. (2012) The impacts of the economic crisis on the spatial organization of Hungarian industry. European Urban and Regional Studies 19(1): 62-76.

Korec, P., Ondoš, S., Rusnák, J. (2016) Regionálne disparity na Slovensku: niekol'ko poznámok k ich bádaniu. Acta Geographica Universitatis Carolinae 60(2): 257-293.

Kraft S, Halás M, Vančura M (2014) The Delimitation of Urban Hinterlands Based on Transport Flows: A Case Study of Regional Capitals in The Czech Republic. Moravian Geographical Reports 22(1): 24-32.

Lee N (2012) Grim down South? The Determinants of Unemployment Increases in British Cities in the 20082009 Recession. Regional Studies 46: 1761-1778.

Maier K, Franke D (2015)Trendy prostorové sociálněekonomické polarizace v Česku 20012011.Sociologický časopis 51(1): 89-124

Martin R (2012) Regional economic resilience, hysteresis and recessionary shocks. Journal of Economic Geography 12: 1-32.

Martin R, Sunley P (2006) Path dependence and regional economic evolution. Journal of Economic Geography 6(4): 395-437.
Martin R (2010) Rethinking regional path-dependence: From lock-in to evolution. The 2009 Roepke Lecture in Economic Geography. Economic Geography 86: 1-27.

Martin R, Sunley P, Tyler P (2015) Local growth evolutions: recession, resilience and recovery. Journal of Economic Geography 8(2): 141-148.

Martin R, Sunley P, Gardiner B, Tyler P (2016) How Regions React to Recessions: Resilience and the Role of Economic Structure. Regional Studies 50(4): 561585.

Masik G, Rzyski S (2014) Resilience of Pomorskie region to economic crisis. Bulletin of Geography 25: 129-141.

Melizia EE, Ke S (1993) The fluence of economic diversity on unemployment and stability. Journal of Regional Science 33(2): 221-235.

MLSA (2014) Gateway of the Czech Ministry of Labour and Social Affairs. Ministry of Labour and Social Affairs, Available online at: (http://portal.mpsv.cz) (accessed on April 2017).

Monsson KCH (2015) Resilience in the city-core and hinterland: The case of Copenhagen. Sage journals 30(2): 191-214.

OECD (2012) Redefining Urban: a new way to measure metropolitan areas. OECD, New York.

Pauhofová, I., Želinský, T. (2015) Regionálné aspekty príjmovej polarizácie v Slovenskej republike. Politická ekonomie 6: 778-796.

Pavlík, A. (2016) Odolnost českých nemetropolitních regionů.In: Výroční konference ČGS 2016: Geografické myšlení jako aktuálně společenská výzva 5.9.2016. Jihočeská univerzita, České Budějovice, pp.204-216.

Pavlínek, P., Ženka, J. (2010) The 2008-2009 automotive industry crisis and regional unemployment in Central Europe. Cambridge Journal of Regions, Economy and Society 3: 349-365.

Phelps AN, Ozawa T (2003) Contrasts in agglomeration: proto-industrial, industrial and postindustrial forms compared. Progress in human geography 27(5): 583-604.

Pileček J, Červený M, Klíma J (2010) Vybrane poznatky dopadu hospodařske krize na situaci jednotlivých regionů Česke republiky. In: Ministerstvo pro místní rozvoj (ed.) Výzkum pro řešení regionálních disparit v České republice. Ostrava, pp. 53-62.

Rodríguez-Pose A, Fratesi U (2003) Regional Economic Cycles and the Emergence of Sheltered Economies in the Periphery of the EU - discussion paper. University of Jyväskylä, Jyväskylä.

Slach O, Ženka J (2017) Post-Crisis Spatial Development of Creative Industries - Evidence from 
Czechia In: Chapain C, Stryjakiewicz T (2017) Creative Industries in Europe. Springer International Publishing, Cham.

Sýkora L, Mulíček O (2012) Urbanizace a suburbanizace $v$ Česku na počátku 21. století. Urbanismus a územní rozvoj XV(5): 27-38.

Toušek V, Novák V (2012) Ekonomická krize a trh práce v České republice. Regionální studia 1: 38-52.
Ženka J, Novotný J, Slach O, Květoň V (2015) Industrial specialization and economic performance: A case of Czech microregions. Norwegian Journal of Geography 69(2): 67-79.

Ženka J, Novotný J, Slach O, Ivan I (2017) Spatial Distribution of Knowledge-Intensive Business Services in a Small Post-Communist Economy. Journal of the Knowledge Economy: 1-22. 